
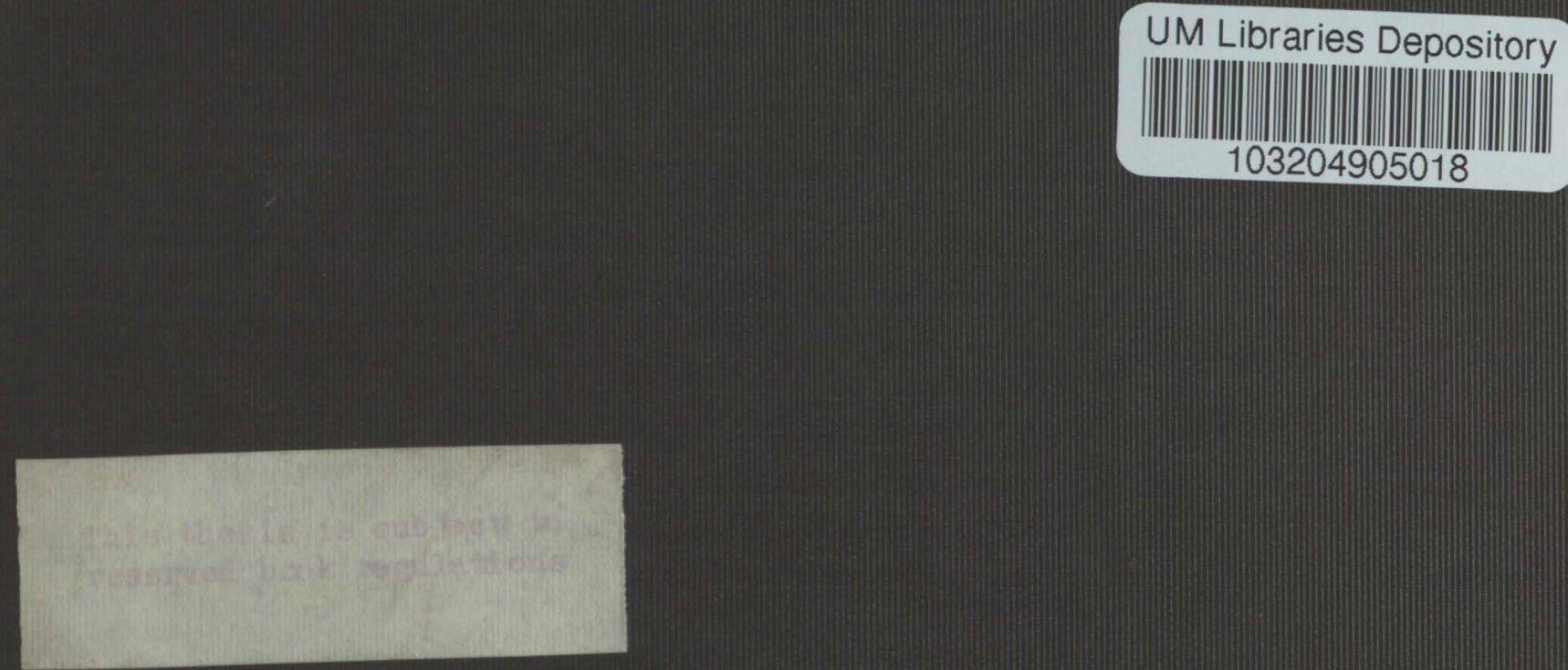


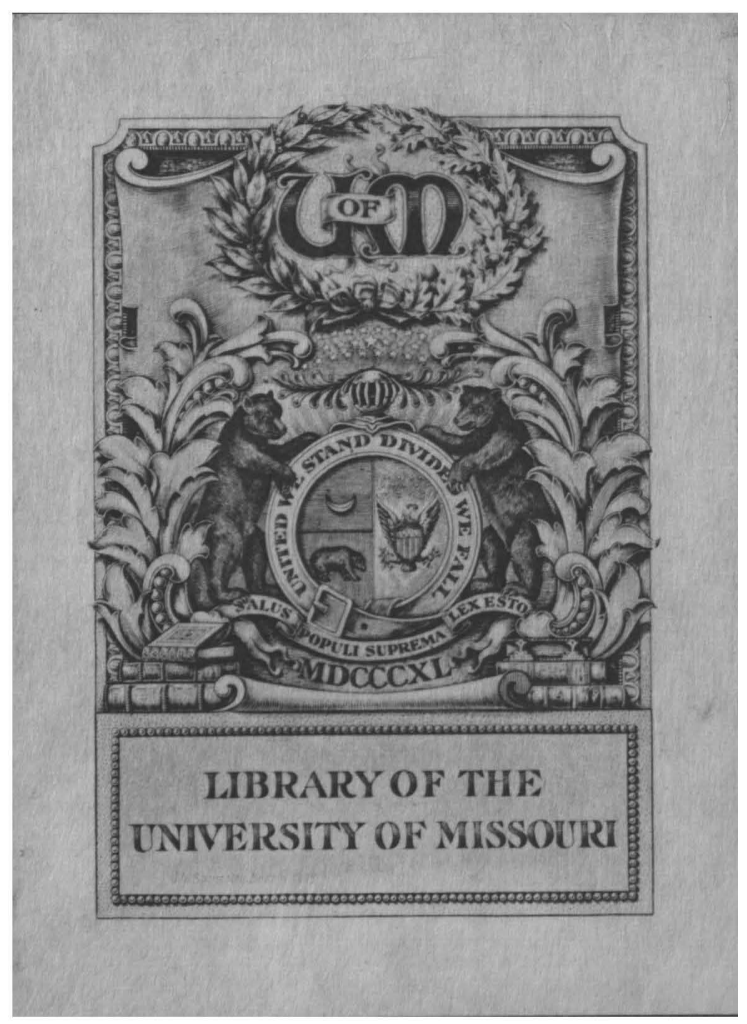

This Thesis Has Been

MICROFILMED

Negative No.=T- 281

Form 26 






\section{AN ANALYSIS OF PRODUCTION COSTS AND APPIICATIONS HIGH COST OF LIVING AND PANICS AND DEPRESSIONS}

BY

$$
\text { George Po Comer, A. B. }
$$

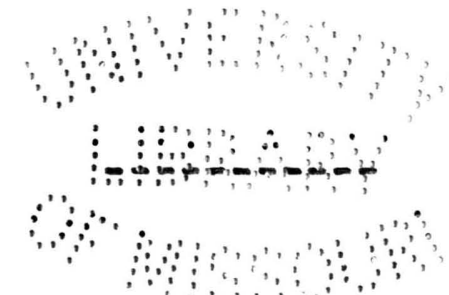
SUBMITTED IN PARTIAL FULFILIMENT OF THE REQUIRFMENTS FOR THE DEGRFE OF MASTER OF ARTS in the

GRADUATE SCHOOL

OF THE

$$
\begin{aligned}
& \text { 'Pproore 2s } \\
& \text { Mlesti.s Thase's } \\
& \text { Bformpul - }
\end{aligned}
$$





\section{BIBLIOGRAPHY}

Veblin.

Theory of Business Enterprise. Chapter 7.

Lyon.

Capitalization. Chapter 3.

Davenport.

Value and Distribution.

Cole.

Accounting and Auditing. Chapter 15.

Cole.

Accounts. Their Construction and

Interpretation. Chapters 10 and 19. 



\section{OUTLINE}

AN ANAIYSIS OF PRODUCTION COSTS AND APPLICATIONS

HIGH COST OF LIVING AND PANICS AND

DEPRESSIONS

Chapter I.

Section 1.

Introductory:

The term porduction Cost used instead of Cost of Production. Reasons.

section 2 .

Opportunity cost.

(a) Opportunity Cost and Marginality.

Section 3 .

(Dollar) Cost of Production.

(a) Cost of production by the Machine Hour method.

(b) Idle Time Costs and Proportion of Factors.

Average Cost and Supply.

Chapter II

Applications.

The High Cost of Living.

Section 1.

\section{Section 2 .}

Production Costs and Panics and Depressions.

(a) Depressions.

(b) Idle Time and Depressions.

(c) Panics and Obsolescence and Idle Time. 



\section{AN ANALYSIS OF PRODUCTION COSTS AND APPLICATIONS \\ HIGH COST OF LIVING AND PANICS AND \\ DEPRESS IONS .}

Chapter 1.

Paragraph 1.

Introductory.

This discussion of cost of production, or as we choose to name it, Production Costs, will be made from the standpoint of the competitive or price economy. Other views of costs, such as labor costs, pain costs, and collectivists costs, however necessary they may be for certain purposes, are not the stress points in the present entrepreneur economy.

We shall not only limit the first part of the discussion to the entrepreneur analysis but shall confine it cheifly to the one great reason why economists are concerned with cost of production; namely, to determine the limitations upon supply. Other aspects of the problem, ethical, sociological and the like, however important they may be for other purposes, will not be included, to any considerable extent, in the present presentation.

Altho most economists writing at the present time have clearly in mind the chief purposes of cost analysis and also, for the most part, accept the entrepreneur point of view, yet a large part of their traditional definitions and analyses are a part of the presuppositions of another economy and do not include all the factors that ordinarily act as determinants upon supply in our present economic life.

One of the important factors, for example, of ten implied 

but generally neglected in studies of costs, is opportunity cost,as all know who read Davenport. Probably most "competitive" economists agree with Davenport that cost of production should include opportunity cost, i e necessary profit, but they generally use the term, often nesessarily, in the narrow sense of dollar cost of production; and, to the ordinary reader, unless directly warned to the contrary, the term has the narrow connotation wherever he finds it. This business-man's use of the term is so ground in our thinking that any rational decision to read into it a different meaning than customary is not oufficient, without effort, to overcome our old habits of thinking.

On account of these and other difficulties with the term I shall, in this paper, use "Cost of Production" in the old dollar cost sense and employ the term "Production cost" to cover the concept of the measure of the sacrifices necessary to the production of a comodity. This term, tho bordering on bad rhetoric and, in denotative qualities, means the same as cost of Production, has, nevertheless, enough of connotative differences, or at least it is hoped that the distinctions to follow will give it enough connotive differences, to justify it's usage as against the old but indefinite term.

In the first place, "Production Costs" lays the emphasis upon productivity. The old term, "Cost of Production", is usually interpreted merely "Cost" and the point of emphasis for the limitation upon a supply is entirely neglected. It is hoped that in putting "Production" fisot the significance of costs will loom larger. Again, the plural of cost is used;- to emphasize the fact that there are more than one kind of cost. In the third place, the very fact that the two terms "Cost of Production" and "Pro- 

duction Costs" are used may lead the curious into valuable discoveries while seeking the distinction between the two.

Using the term Production Costs, then, to indicate the expression in terms of dollars of the total sacrifice in production we may divide the concept into the components, Opportunity Cost and cost of Production. The latter may be divided into the average cost of one of a number of articles as determined by the cost accountant, and the "actual" cost of specific commodities or the added expense when one more of a given class of articles is produced.

Section 2.

OPPORTUNITY COST.

In view of it's consideration by it's chief exponents a detailed discussion of Opportunity cost is unnecessary, but it is not amiss to reemphasize the fact that one of the large determinants of the supply of a given commodity is the opportunity to make a profit by producing other commodities. It is also important for some purposes to recall that opportunity cost arises largely in a contemplation of the probable state of the different markets of finished product with especial emphasis upon the probable demand schedule of such products, whereas the (dollar) cost of production is based upon the market price of productive agents. When each entrepreneur contemplates production he is confronted with a whole complex of environmental factors a barge part of which is the market price of his productive agents yet an equally important class of factors is presented by the probable market, and especially the demand side of the market, for different classes of finished products which he could produce. From this forward 

looking guess he determines his opportunity cost. It is true that the probable supply of finished products is just as important for future market prices of fintshed goods as the future demand but seemingly the more careful study is dirceted toward the demand side.

In ordinary short time, smoll entrepreneur analyois these distinctions as to the basis of opportunity cost as against cost of production may be inimportant but, as we hope to see later, the practical problem of the high cost of living is largely explained by a study of opportunity cost as determined by a shift in the kinds of consumptive goods demanded. OPFORTUNITY COST AND MARGINAIITY. Probably the most important phase of opportunity cost is to be found in it's relation to the doctrine of marginal cost. The ordinary statement of the derivation of marginal cost of production is that a man will extend his productive energies along each line until the last dollar, or unit of capital, expended for an agent of production will just be returned in the value of the product made by such agent, or, in better form, we may find the statement ending " until the added product (from the whole complex) just returns the dollar spent when it was produced".

This statement id clearly inadaquate unless "spent" is stretched to include necessary profit as well as interest. An economist would have great difficulty in convincing a business man that he should continue to invest his money in his business until his last hundred, say, brought no surplus return. He probably would pass it off by the trite statement that he wasn't in business for his health. Or that he would not undergo the risk and labor for less than $15 \%$ on his investment. 

That is to say the marginal doctrine should read that a man will invest in agents of production until the last dollar, or unit, invested will be accompanied by a value return equal to the dollar plus the surplus return on the next best opportunity. Even in strict theory it is doubtful if Professor Tausig is right when he implies that the ordinary rate of interest is the limit of the surplus at the margin because in modern methods of financing the risk element is so large that one's creditors will scarcely let him spread out his equity in the business so thin as to earn only $6 \%$ or $7 \%$ at ith margin.

In ordinary non-marginal production opportunity cost may not loom large but, with relatively fixed markets for productive agents, as a margin of investment is approached the opportunity to put the dollar elsewhere becomes the object of keenest consideration. There isn't much question in the farmer's mind but that he will plow his corn three times but the fourth plowing as against hay harvesting is a serious question for him.

In the relative world of economics one may say, in a sense, that opportunity costs are alone the determinats of margins in production.

\section{Section 8 \\ COST OF PRODUCTION.}

As indicated above one great subdivision of cost of production is the average dollar cost of production as determined by the cost accountant. The accountant's method of cost determination is coming more and more to be considered as the ultimate cost analysis and the cost which in reality determines supply. Such complex and almost automatic cost systems as are installed in our large manufacturing plants are, if not awe inspiring, 

at least admirable pieces of ingineering skill.

When one studies scientific exactness with which an awful chaos of detail is marshalled under a few simple categories like "machine hour" or "labor hour" one is constrained to say "Here we have the analysis of the real cost of production. All others are approximations; this method is the one the truth loving physieist would use should he attack the problem".

Yet, after all, with all it's admirable exactness, the costs found are average costs, and as such, in view of the law of diminishing and increasing returns, they cannot represent actual dollar costs of a given article in the whole class. Or more properly the average sosts will not give the difference in expenditure in producing one article more or less after the others are produced. More of this later however.

It must be noted; nevertheless, that to the extent that the entrepreneur believes that his cost accountant has given him the"last word" on costs to that extent do average costs become difinitive in the forth coming supply. Competition however is likely to lead him to another difinitive concept of costs.

Before further questioning the adequacy of cost accounting for our purposes, we may well give in outline a cost system partyy discussed by Cole in accounting and auditing. Chapter 15. COST OF PRODUCTION BY MACHINE HOUR METHOD.

Nany different methods of figuring costs are used depending upon the technique of preduction. The chlef divisions of these are "process method", "machine hour method" and "labor hour method". For our purposes we shall discuss the "machine hour method" 

Roughly defined, this method consists of centering all costs, or as much as possible in the use of a machine for a unit of time, say one hour, The "Machine Hour" then is the total costs of using a given machine one hour.

The cost of a "machine hour" is made up of the flolowing;

(1) Space Cost.

(2) Machine Costs.

(3) Machine use Costs.

(4) Power Costs.

11) The space cost is based upon the proportion of space the machine requires out of the total space. If the toatl floor space cost $\$ 3000$ per year and a given machine occupied one thirtieth of it; obviously the space cost for this machine will be $\$ 100$.

The total space cost is composed of the following expenses:

(1) Interest (or rent) on the investment on land and the building.

(2) Repairs on the building.

(3) Depreciation on the building.

(4) Insurance and taxes on the building.

(5) Heat and light.

Take the proportionate share of this burden for each machine.

(2) The Machine Costs are:

(1) Interest upon the cost of the machine.

(2) Repairs due to non-use.

(3) Depreciation due to obsolescence of pattern.

(4) Taxes and insurance on a machine. 

(3) Machine use costs are:

(1) Direct expenses such as oil, cleaning etc.

(2) Repairs due to wear.

(3) Depreciation due to wear.

(4) Share of superintendence if possible.

(4) Power costs. Proportionate share of total horee power used. The total power costy is made op of three general costs above, ie, space costs of the power plant. Machine costs of dynamos etc. and machine use costs including fuel, labor etc.

Suppose for an example, the costs on a given machine were for a year,

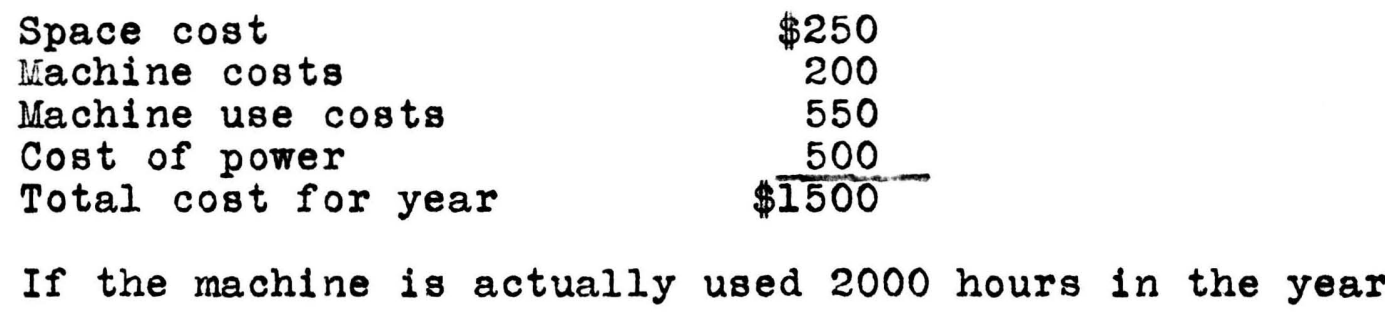
evidently the cost per hour is $75 \not$. That is, any piece of work upon this machine must be charged $75 \not$ per hour as it's share of the minlitude of costs.

If a record is kept of the machines used and the time on each job, the total expense for use of the machinery may be obtained and if to this is added the cost of raw material and the labor employed on it together with the proportionate share of office expenoes, we may obtain, with great accuracy, the average cost of the items in a job of work.

It will be observed however that all machine costs are based upon the cost for a past fiscal period and if actual expenses for the current period are different an adjustment must be made on the cost books at the close of the period. in fact tisis 

adjustment account showing the amount of error in either direction becomes important for the business manager.

Perhaps it will be well to further explain the matter of tracing a portion of a hypothetical"job" of work thru an equally hypothetical cost sheet. (Bee $q a$

Suppose the job under consideration is the making of 100, 14 inch walking plows. The cost sheet appended represents the cost of making the beams, say, of the plows.

At the top of the order is found the kind, amount and cost of the raw material, and in the checkerboard squares below is found the analysis of machine and labor costs. Each machine is numbered and the number placed at the top of the columns, as, II 2/3. The Ioman two being the machine number and the index $2 / 3$ being the fraction of full time the machine ran during the past fiscal period. In actual practice this index need not appear on each job order yet we now put it there for simplicity in discussion.

In the first perpendicular column will be found the workman's number and whenever he uses a machine he puts his number in the proper place and running but horizontally, he puts the number of hours he used the machine under the proper machine number. Thus when the job is finished the total hours on each machine is found by adding up it's column. Under the total hours for each machine is found the machine-hour cost, determined by the method detailed above. By multiplying the total hours on each machine by it'g machine-hour rate we get the charge for each machine. The grand total of machine costs is found by adding the horizontal machine costs. This grand total id extended in the main columns to be added in with other costs. 

Job Order No.

Date 19

RANKIN MFG. CO.

\begin{tabular}{|c|c|c|c|c|c|c|c|c|c|}
\hline No & Kind & Quan & Cost & Amoun & & Overhead & & & tal \\
\hline $\mathrm{X043}$ & $\begin{array}{l}\text { Raw Plofh } \\
\text { Beâms }\end{array}$ & 100 & 55 & 55 & 100 & 5 & 0 & 60 & 00 \\
\hline
\end{tabular}

Total Material Cost

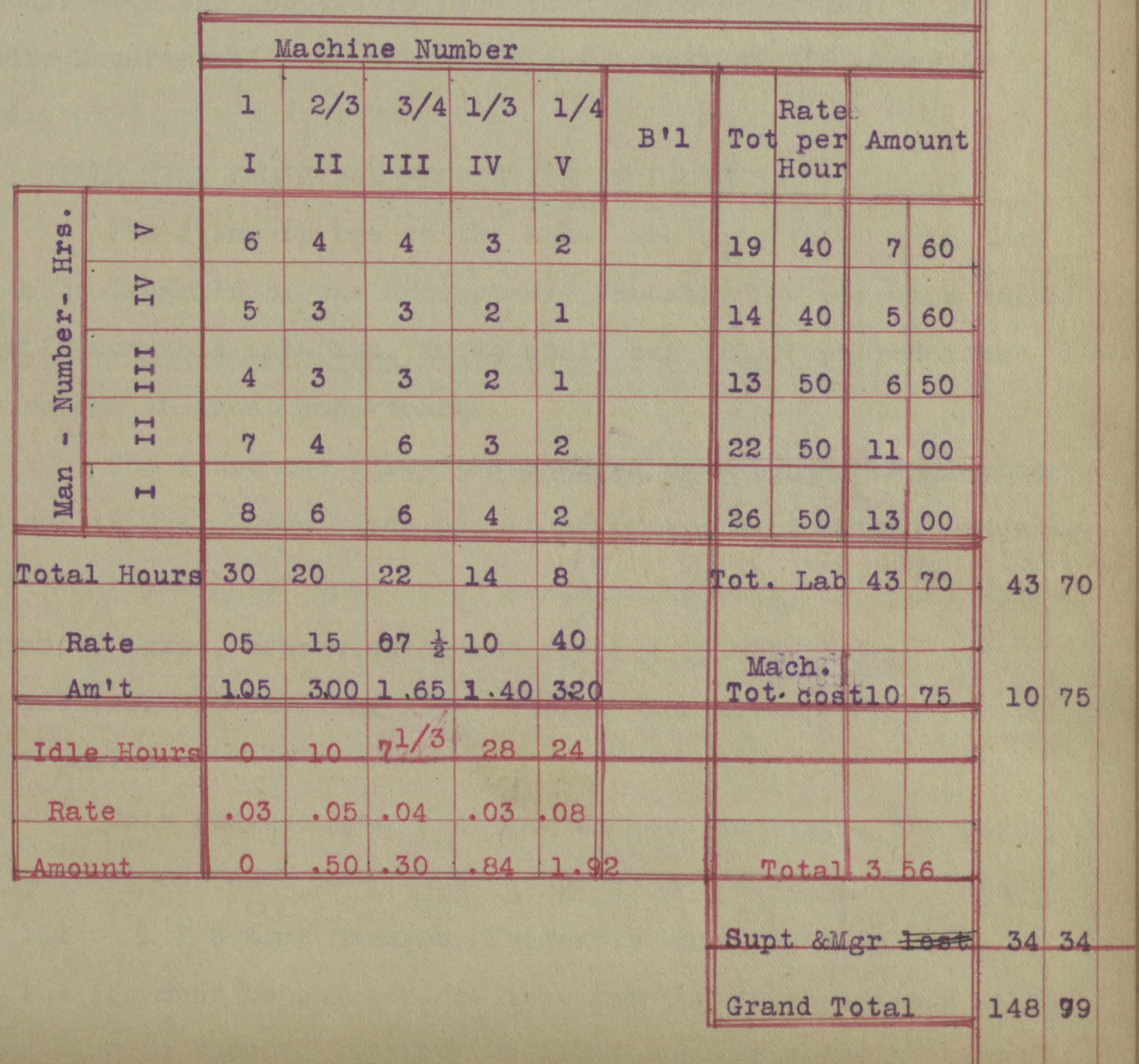



Another cost yet to be calculated is labor cost. By adding the horizontal columns in line with each man's number we find his total hours on the job; multiplying this by his wages per hour we find his labor cost. By adding this cost of labor column we get the total of labor costs, which we extend in the main column with machine costs and raw material.

Another cost that may be added here is the share of administrative expenses that this job order should carry, altho this could be added later.

This job order for the beams goes in to the accountant together with the job orders from the "Share Department", the "Handle Department" etc, where the total cost of 100 plows is fount.

IDIE TIME COSTS AND PROPORTION OF FACTORS.

The items in red on the sheet are additional data that are to be inserted by the accountant. Probably few concerns will actually use this data but, as we shall see under"applications" they become of great importance.

The items are idle time charges or expenses of machines when not in use. These rates are found by taking the total expenses under $I$ and $I I$ of space cost and machine cost, ie, interest, insurance, taxes, depreciation and repairs upon buildings and upon machines and dividing this total by the normal hours for the fiscal period.

This non-use hour cost may be used to figure the idle time charges for each job, thus, suppose the non-use hour rate were $15 \not$ on a $2 / 3$ time machine. Evidently when the machine is used the job must be charged not only for the fixed charges while the machine is running but for the fixed charges when it is not 

running in order to get true costs. That is the fixed charges on a $2 / 3$ time machine when the non-use hour is $15 \not$ must be $15 \not$ plus $7 \frac{1}{2} \not$ or $22 \frac{1}{2} \varnothing$.

Each hour on a machine must be charged $7 \frac{1}{2} \not \subset$ for idle time,-. $7 \frac{1}{2} \notin$ that should not be there in a well balanced factory. It will be observed that the idle time charges have all ready been counted in as a part of costs, yet they are so important in a competitive situation that they may well be kept separate for the information of the entrepreneur. To the extent that the items appear to such an extent is the factory "off" from an ideal proportion of factors and by so much is the entrepreneur handicapped in the competitive struggle.

In our example on the cost sheet the nature of the work is such that some of the machines can run only $1 / 3$ time and yet keep others running full time. Thus we have the indeces $1,2 / 3, \frac{3}{4}$, $1 / 3$, with a total idle time handicap of $\$ 3.56$ whereas a large competitor having a better proportion of productive agents has less costs to meet and can undersell the small man by at least, the difference in ide time charges.

If one is curious to know what is the best proportion of factors in the industry so far as the numver of machines is concerned, cost aside, he may find it as follows: Reduce these fractional indeces to a common denominator; thus $1,2 / 3, \frac{3}{4}, 1 / 3, \frac{1}{4}$ equal $12 / 12,8 / 12,9 / 12,4 / 12,3 / 12$. The numerators, $12,8,9,4,3$ represent the number of machines where there will be no idle time charges; for each set of machines will keep all of the others busy. This will be the ideal technological proportion of factors and a concern having his proportion would have the competitive advantage over any smaller concern and over any larger 

concern up to double the proportion, ie, $24,16,18,8,6$. From this It will be seen that advantage of size is not necessarily a mere matter of amount of capital invested but it is, to a considerable extent, a matter of proportion. Certain sizedconcerns have the advantage over larger or smaller neighbors. Thus the ideal proportions run, for number of machines: $12,8,9,4,3 ;-24,16,18,8,6$; $36,34,27,12,9$ etc where no idle time charges will enter in. On other proportions, larger or smaller, idle time will be in evidence.

Not only do these ratwos of combination show the best technological arrangenent but they form the basis of an ideal capital outlay. Suppose for example in our cost sheet that one machine cost $\$ 1000$ per year, another $\$ 500$, another $\$ 300$, a fourth $\$ 200$; and the other $\$ 100$ and suppose the full time machine could handle 1000 items per year; then the total machines cost of this volume would be $\$ 1000$ plus $\$ 500$ plus $\$ 300$ plus $\$ 200$ plus $\$ 100$ or $\$ 2100 \ldots 219$ per item. On the other hand the factory having the combination of machines \#1-12, \#2-8, \#3-9, \#4-4, \#5-3 could put out 12000 items at a total machine cost of $\$ 1980$ or $\frac{\$ 16}{1,6}$ apiece. That is, the larger factory would have the advantage of 4.45 Item in machine cost. This is upon the assumption, however, that the buildings, labor etc, cost no more proportionally than in the small concern.

\section{section $\%$}

AVERAGE COSTS AND SUPPIY.

It must be insisted nevertheless that the above analysis of costs, however minute it may be, is an analysis of average costs. That is, it is an analysis of the total cost of producing a given number of items and if the number of items to be produced 

is changed the average cost per item will probably change. Therefore, past costs, except in a general way, cannot tell the costs for a future and different sized order. In a past fiscal period a man's average costs per item have been 2.10 when he puts out 1000 yet it may well be that he can speed up a little and put out 1100 at a total cost of $\$ 2200$ or two dollars each in stead of $\$ 2.10$. That is if he could sell his regular 1000 at $\$ 2.10$ plus profit to his old customers he could push into new fields and sell his extra 100 items as low as $\$ 1.10$ each and still make $\$ 10.00$ more profit than he did last fiscal period. Of course his accountant would probably show him that each item he sold at $\$ 1.10$ really cost him $\$ 2.00$ yet his answer is, "May be so, but I am $\$ 10.00$ better of than if I hadn't taken the order. The truth is, average costs will not determine the supply in any one market. The entrepreneurs lookout is that he shall sell his total supply in many markets for a sum greater than his total cost but his refusal price in any one market need not reflect his cost of production. This of course id the heart of cut throat competition. It may cost a railroad company $\$ 1000$ to take a train of 40 cars from St. Louis to Chicago yet they probably could take on another car and take the train for $\$ 1005$, say ${ }_{x}$. That is the accountants average costs may be about $\$ 25$ per car yet a profit can be made by hauling the forty first car for anything above five dollars.

It is thus apparent that the accountant's costs however exact they are, plus opportunity cost, however closely estimated It is, cannot exactly explain the supply of commodities in a given market. In our first case our average cost is $\$ 2.00$ per item, a manufactror may wisely throw an added hundred items on the market even tho he gets but $\$ 1.10$ apiece for them, for in this 

case he gets $10 \%$ on his added capitol invested. It is true that in the long run average costs plus opportunity costs will determine supply in a general way but not in a specific market.

It must be repeated, however, that to the extent that the entrepreneur accepts his accountant's costs as final they may act as determenants ufopn supply but sharp competition is likely to lead him into the production of the few extra items which may be sold at less than "costs".

Production costs then are the monetary expreesions of the total sacrifices to be undergone by a particular entrepreneur in putting on the market a given number of items when he has a given technological equipment runnigg at a given capacity.

Not only are production costs ifferent for different entrepreneurs but they are different for the same entrepreneur in different situations. Often a man could increase his output 100 items without adding greatly to his total expense whereas at an other running capacity he could not materially increase his output except at great expense.

The emphasis in costs is upon the particulars in the case, - particular entrepreneurs, particular number of items at a particular running capacity.

(Note) If the entrepreneur desires the accountant's figures in the computation for an added number of items over the present capacity he may obtain them by a study of total costs in previous periods with theirn different volumes of output. For example if it is found that previous periods show that when the output was 100 items the cost was $\$ 2.50$ each; when 500 it was $\$ 2.25$ each; 750 cost $\$ 2.15$ and 1000 it was $\$ 2.10$, some progression of decreasing costs might be obtained which would aid in estimates for additional products. 

CHAPTER II.

Applications.

Section 1 .

The High cost of Living.

It will be recalled that, in the discussion of opportunity cost it was maintained that such costs arose, in the most part, from the consideration of the actual and probable demand schedule of the alternate finished products, and that, in the long run, these costs were important factors in the high cost of living. The vital part of the problem of the high cost of living to the great mass of people is not so much the question of the high prices of all commodities but rather it is the prices of forty or fifty of the basic necissities that is important. Directly, it is no concern of most men as to how expensive are "diamond back" turtles or "canvas back" ducks or steam yachts or even English Teed or French millinery; yet, in an indirect way the prices of such luxuries are very important: for to state the matter somewhat epigrammatically, the high price of things the ordinary man does not buy is an impottant cause for the high price of the things he does buy. That is, the high prices of necessities are due to their relative scarcity and their relative scarcity is largely due to the fact that owing to the conditions of demand more money can be made in producing luxuries than in producing necessities. In other words, the opportunity cost id too geeat for men to produce pigs and wheat. More money can be made in producing automobiles. For example, the Studebaker wagon that sells for eighty dollars today could be bought fifteen years ago for sixty dollars. Doubtless this rise is due of course to several causes, but probably the most important one is that; whereas, 

fifteen years ago the studebakers found it most profitable to make prosaic farm machinery, they, now find it most profitable to directa large part of their fifty millions of capital to making automobiles. The same is true of a large number of big motor factolies in this country. In numerous automobile advertisements one reads that the firm has been in business from twenty five to one hundred years, yet, prior to ten years ago they made carriages, wagons and farm machinery. It is true indeed that the cost of production of wagons is higher than formerly but this to a considerable extent due to the fact that men and material are drawn into the automobile industry, a matter of opportunity cost again.

To get a little deeper into the matter at the risk of getting away frorn text we may say that this great demand for luxuries as against "necessity" is largely due to the fact that we have in America a very large class of people with incomes of $\$ 2000$ and over.

Probably one half or more of this income goes to the purcahse of socalled "necessities",- sophistical forms of the primal necessities; yet in the comsumption of flour, meat, and ordinary clothing even the millionaire doesn't go a great deal further than the dock hand or grocers clerk. That is no matter how large a man's income the demand for pigs and wheat is not greatly increased. But in the two thousand dollar class and above, a larger and larger proportion of each man's budget goes for the purchase of the refinements and flummeries of modern life, until the millionaire probably spends ninety per cent of his income, sooner or later, for consupption goods that it takes an army of men to make. It is an old story that a great docial 

function, the work of thousands of men and women is eaten up, drunk up, and burnt up in a few moments; Whereas if conditions of demand had been otherwise it might have been more profitable for entrepreneurs to direct their energies towards raising potatoes and corn, instead of humming birds and wax flowers. Aman from New England recently remarked to me that around Boston there was now no money to be made in raising sugar corn and cabbages but $\Varangle$ that the money was to be made upon elite vegetables such as celery, cauliflower and various garnishments. The opportunity cost of carrots is so great as to reguire a high price if they are to be produced.

It may be objected that since the rich have the money they had better spend it in some way or another even tho it be in riotous living; and, that as a matter of fact they spend a large portion of their income in productive enterprises that give employment to thousands. This of course is the point at issue. It is not decisive that the rich build factories; the question is, what do the factovies produce? As well consume the income in luxuries in the first place as to aggravate the matter by using it to produce further "useless" luxuries. The whole point is that the high sailing strata of society are, by their spending for things the common man does not need, sucking up into their samewhat lurid wake and out of reach of the many, great streams of laborers and raw material which, in an endless chain fashion, go to minister to the rich, leaving few entrepreneurs below to raise pigs and wheat.

Note:

It must be understood that this is but an attempt to explain an important phase of the high cost of living and not a condem- 

Note Cont.

nation of the present social order. The rich are not necessarily to blame; Our whole cry for "higher" things, from fine art and academic education to areoplanes, all discourage the production of pigs. Id Inot, myself, hope never to plow a row of corn or sow a field to help reduce the cost of living but rather hope to explain why others should do it? To get particularly gloomy, we may say that the more men drink of the fierien spring and the more they are touched by the firs of exquisite consumption the higher will go beef-steak.

It is also not to be implied from the discussion that the poorer classes would be any better off if the rich spent for beef-steak and flour instead of for automobiles, Indedif the rich spent their enormous incomes for necessities the common man would have to pay higher prices than he now does on account of the law of diminishing returns applying in the incustries where necessities are produced under this "forced" demand. Nor is it entirely clear as to the ultimate effect if the rich got the large incomes and spent or invested none of it except for ordinary living. Fortunately however we are not here called upon to solve this problem. But so much of the facts are certain however, namely that the rich can't spend much of their incomes for necessities and do spend it for luxuries and probably no matter what they do with their incomes whether buy yacts of potatoes or hoard them or dump them in the deep sea to the extent that they get large incomes at all by so much shall others be disadvantaged and by so much shall flour, wool, and meat be hard to obtain. 



\author{
Section 2 . \\ PRODUCTION COSTS AND PANICS AND DEPRESSIONS. \\ To begin withit must be emphasized, as Veblin of ten
} points out, that panies and depressions are primarilly psybological matters. It is the emothions of men that largely account for financial and industrial crises.

\title{
DEPRESSIONS
}

Here, as in all economies matters thereare two sets of forces working in combination to cause the industrial upheavals and readjustments, ie, the fores on the demand side and those on the supply side,. Our text forbids us to go to any great length into the demand side of the depression but it may be noted that the expenditure of the larger portion of the budget of the well to do classes for the luxuries rather than for necessities means that a large portion of the country's productive energies are engaged in producing goods for which the demand is elastic. That is, much production is of goods that, if occasion demands men can dispense with for several weeks or months, to the great disturbance of industry. In times of stress men go on rampages of restricted expenditure and the wealthy may, for a time, buy but a comfortable living, - not because they have not the means but because it is against one's psychology to want automobiles and great dinners when one's nominal capitalizations are tumbling or even when one is afraid something will tumble. The very terms "large spending for luxuries" is sufficient to indicate what will happen to business when men become alarmed. As to the supply side of the matter we may hark back to the (dollar) cost of production and see it's special bearing 

upon depressions.

In the study of factory costs it will be recalled that one item under machine costs was "depreciation"from obsolescence! $x$ And, aso, that at the bottom of the cost sheet were items written in red labeled "Idle Time"

Depreciation and depression may be considered first. In certain lines of production the depreciation from obsoledcence on the machinery may, become as important factor as depreciation from wear, and it may become a more dangerous force in the competitive struggle on account of it's subtility and irregularity. The wear on a machine is a thing relatively obvious and measurable but the obsolexcense of a model is something that goes on unseen and unheard; for, some dreaming chemist pr physilist may, overnight, make thousands of dollars worth of machinery useless in a competitive struggle. It is often said that the prosZa concern perity may be judged by the largeness of it's scrap heap. Sometimes the immediate installation of new models, even tho the old models are new machines, is the thing that determines the survival of the given concern. There is but slight question what will happen when $A$ keeps an old model that costs $\$ 5000$ and turns out 500 units of production in a day, while his competitor, $\underline{B}$, buys a new model for the same money that puts out 750 units. In This case, as in many others, the business welfare depends upon the little item of cost, - depreciation from obsolescense.

Note;

For a full discussion of relation of "Depreciation from Obsolescense"to depressions see Veblin. Theory of Business Enterprise. Chapter VII. 

It is indeed true that no definite amount to be written off (ie, charged to expense) can be determined, because one cannot exactly know what Edison has up his sleeve; yet, in the long run, improvements come by somewhat regular increments and even if they are quixotic, the point is half gained when men recognize the importance of watching this " $X "$ in their cost.

Not only is the obsolescense of machine models important but whole systems of factory management may become obsolete to same direful extent as machinery. Obsolete cost accountang, and old fashion ways of management in general may be as disasterous in the competitive struggle as old models. The trouble is, obsolescence of all sorts usually go together and the factories whelte it is found in it's most"virulent" form are the ones where, an account of old cost system, it's presence is least known. In the small factory where costs should be figured to a penny they If are usually guessed.) Perhaps the wonder grows as to what all this has to do with business depressions.

To reiterate: depressions are largely psychological matters. When $x$ business men see their earnings and hence their "real capital values" melting away for any cause, and especially from an unseen, and large-ly unknown cause, they are depressed and slow to undertake ventures;- (altho in desperations they may undertake adventures) that is wo have stagnate business. Once of the many things that melts away a man's plant values, unseen and unknown, 1s, of course, this depreciation and to all would be sellers, from book-agent to land-lord, he is inclined to say in his own vernactlar "nothing doing, business is dull" 

of course the direct reason why his earnings fall off is because his more up-to-date competitors undersell him. The necessary thing for him to do is to cuty prices to the level but what he probably does do, which amounts to the same thing so far as earnings is concerned, is to keep his salesman in the field quoting out-of-date prices and by consequent his shipments gradually and slowly fall off. Naturally he is correct so far as he is concerned " nothing doing, thmes are dull", Men in business are great individualists, if they, personally, are in hard times the remeinder of the world, as seen thru their spectacles is blue. And of course as this gloomy outlook gegins to spread from the out-of-date men it gathers force as it goes, by the fact that active entrepreneurs selling raw material to these men are finding less and less buyers for their wares. The match may indeed be small but the conflagration great.

IDIE TIME AND DEPRESSIONS.

The other 1tem in the cost sheet having a bearing upon this particular question is, as we have mentioned previously, "Idle Time charges". In the main, the same arguments apply to idle time as to depreciation from obsolescence. They go on subtly and unguessed, just as does deprediation, and the same arguments hold that the small factories, where they are likely to be the most prevalent, is the one that takes the least account of them. Even when idle time is figured it ${ }_{A}$ likely to be merely lupped in with the other costo until the entrepreneur cannot tell just what is his handicap of idleness. About all he knows, again, is that he 

must quote old prices to make a profit and his sales fall off before the onsloughts of his competitor who has discovered and is fliminating his idle time by a better prpportion of factors. (See note page 22a)

PANICS AND OBSOLESCENCE AND IDIE TIME.

These two firces, obsolescence and idle time, also play their part in pan1c times by causing a discrepancy nominal and real capitalization. Securities are issued and especially bonds, upon the basis of plant and property values which values are, of course, a function of the earnings but the subtle forces of obsolescence and idle time, among other things gradually sap the earnings and some bond holder wakes up to find that whereas his paper was in the beginning protected by a more or lesg margin of stockholders equity, is is now protected by a plant and pooperty that will not meet the face of the bonds against it. Foreclosure and radical shifting of industrial control incidental to panic times is the result.

To summarize the section:- the analysis of production costs is essential to survival in competitive business and the man who does not analyse them, especially as to depreciation from obsolescence and idle time finds his capital values(based upon earnings) melting away from causes largely unknown to him. His strange falling off in his profits makes him slow to extend his productive energies and as this condition spreads over a large, field of indutry, both by direct action and reaction, we have a general business depression on foot. 

Note:

Another phase of the relation of Idle Time to Depression is deserving of a section in the text but must, for the present find a subordinate place in a note. This is the entrepreneur's attitude toward Idle Time as a cost when the state of his trade w11l not permit his factory to run full time. In slack times it may well pay the man to run hts factory altho the price of the unfinished products will not remunerate him for his "average" cost of production. A man may are articles for $\$ 2.00$ average cost and sell them for $\$ 1.50$ for the good and sufficient reason that shut down his factory and not run at all would be to lose not only his men, organization, and some machinery but also his customers that it has taken years to obtain. Perhaps for a year or more his watchword is "run at any cost".

Not only doesthis apply to periods of business depresslons but some such situation periodically comfronts most manufacturers in normal times. The volume of trade in each industry varies with the seasons and even with the months and to be a successful manufacturer one must have an equipment large enough to carry the load of rush seasons even tho it be too large a factory for slack or even average periods in the year. For examplefan electrical plant may need a three hundred horse power plant to handle the peak of the load for two or three hours of the twenty four while at other times of the day a small plant would handle the load.

In most businesses it 18 not always imperative that a man shall have a concern that can handle all the load in the rush season but rather he should have a plant that id, in size, the "golden mean"; - not too small to lose him toomany customers in the rush nor too large to eat up his profits

In firms of this sort it may follow that in slack seasons or hours they can well afford to turn out products at much less than it actually costs to produce them rather than let their necessary equipment stand idle. Thus a minicipal light plant can advantagourly sell, if necessary, electricity for industrial purposes during the day af considerable less then cost because they must have a large equipment to handle the 9 P.M. peak any way and all the extra earnings during otherwise idle hours is so much to the good. 

This depression may end or even begin by a crisis due to the discrepancy between real and normal capital vahues.

SUMMARY .

POTEITATON.

An analysis of cost of production is recognized by most economists to be the heart of the competitive economics. This term has so many uses, however, that it was thought expedient to use the term production costs to cover the concept usually meant by the term cost of production, namely, the measure of the sacrifices necessary to bring forth the supply.

The chief categories of costs are, (1) opportunity cost and (2) dollar cost of production of which the latter is subdiveded into (a)average or accountant's costs and (b) specific costs of added items in face of a given productive capacity.

Opportunity cost looks chlefry to the demand side of the finished product and becomes particularly important at the margin of production. This characteristic of it's arising from a consideration of the alternate demand for finished products becomes important in a phase of the problem of the high cost of living; for, the necessities are, at present, not produced in such relatively large quantities as formerly owing to the fact that a growing slass with large incomes have made it more profitable for entrepreneurs to produce luxuries instead of necessities. That is, the opportunity costs of necessities have risen. This oftuation where large investments are in plants for the production of luxuries becomes a lalamitous drag in times of panics and depressions because all men cut down their purchases of luxuries in such times. 

The most important subdivision under costs of Production is the average costs or the accountant's costs. These costs are analyzed with great exactness by several methods an important one of which is the "machine hour" method. By this method two items appear; namely, depreciation from obsolescence and Idle Time charges, the latter of which varies inversely with the perfection of the proportion of factors; which, owing to their subtle working in decreasing the ppofits, and henee the real capitalization, of competitive business men, paay an important part in bringing on panics and depressions.

The other cost, ie, cost of an added item, is based upon the law of increasing and diminishing returns and becomes important in the study of cut-throat competition, because, as the factory runs anyhow, the added product obtained by a little crowaing may increase the toâtl even tho such added items are sold below the average cost of production. $\lambda$ In production costs we have roughly the three forces bearing upon the theory of panics and depression; (1) The precarious conditions of producers of luxuries ine to the elasticity of their customers demands, (2) the subtle influence of obsolescence and idle time in melting away profits and real capital values until the latter will no longer support the credit based upon it; and (3) the tendency toward cut-thooat competition found in special costs, which further reduces earnings to the greater discrepancy between real and normal capitalization. These three tendencies working in all sorts of compotions with others and especially monetary forces, gives us the shifting and uncertain maelstrom of the economic cycle. 

UNIVERSITY OF MISSOURI

ColumBiA

DEPARTMENT OF SOCIOLOGY

Play 23,1963.

Lessor Walter Miller

airman of the Eradiate Committee

Professor miller.

Enclosed is Phr. Comer's dissertation which have d with care.

My principal criticism of it is that the style ir may and involved but it displays a good deal of right into the present economic system and 2 think, quite worthy of acceptance as a aster k dissertation.

Yours verytruty

Maurice Parmele. 

$378.7 M 71$

$\operatorname{xer} 34$

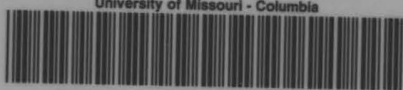

010-100711464

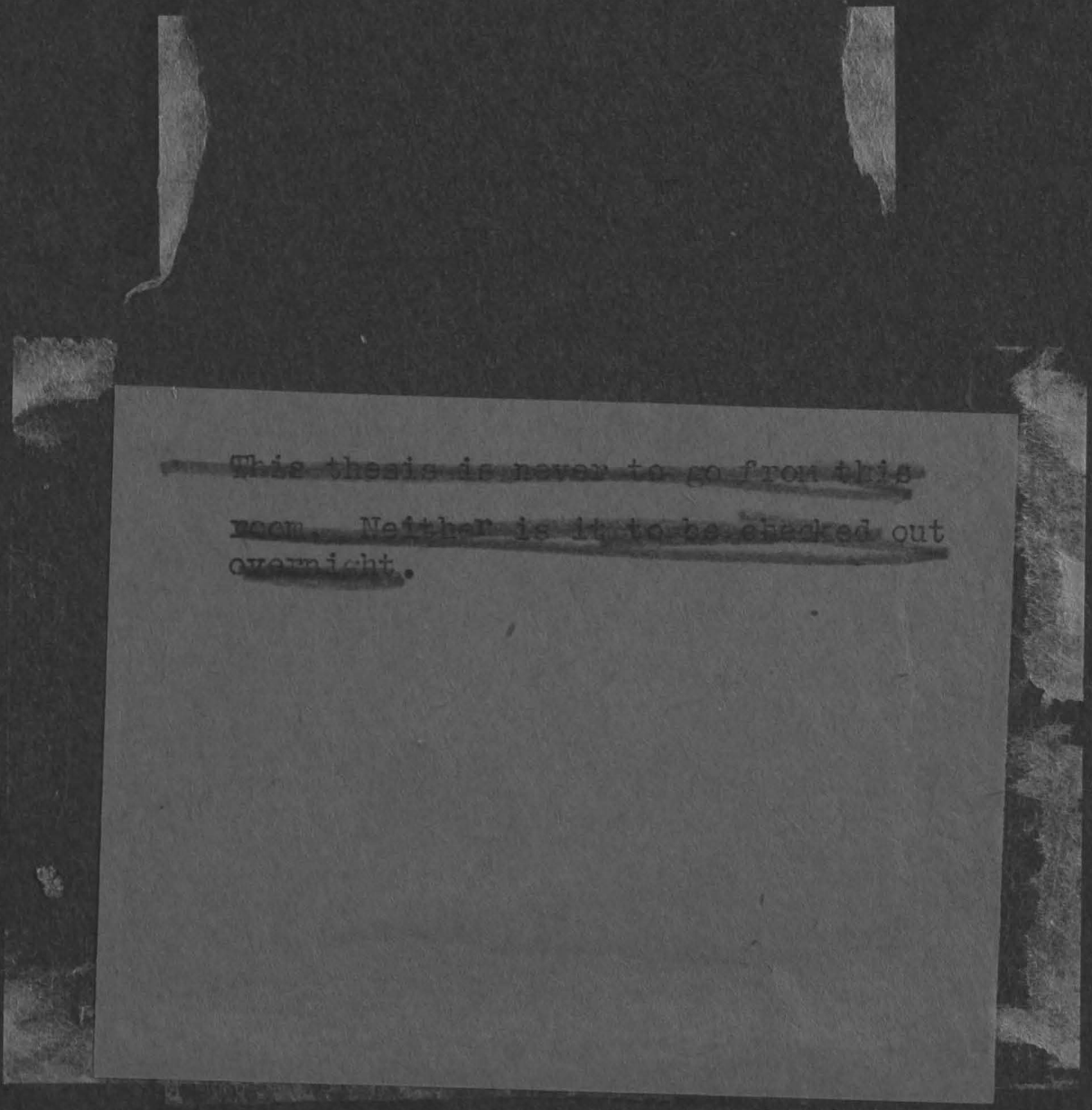


